MICHAE TYMOWSKI

Warsaw

\title{
WOMEN DURING THE EARLY PORTUGUESE EXPEDITIONS TO WEST AFRICA
}

The role of women in the early phase of Portuguese expeditions to Africa has only been discussed incidentally in works on geographical discoveries. Avelino Teixeira de Mota briefly addressed the problem when writing about the garrison of São Jorge da Mina fortress. Joseph Bato'ora Ballong-Wen-Mewuda also made a passing reference to women in the discussion of a broad range of other issues. ${ }^{1}$ Similar in character are some passages in works by Christopher DeCorse and John Vogt. ${ }^{2}$ Paul Hair relegated his perspicacious remarks to the footnotes of his work on the founding of the fortress at Mina (now Elmina). ${ }^{3}$ More extensively the issue has been dealt with in some articles discussing the role of African women in the development of domestic trade networks in West Africa and exploring the networks' links with the Portuguese trade. ${ }^{4}$ However,

${ }^{1}$ Avelino Teixeira da Mota, Alguns aspectos da colonisação e do comércio marítimo dos Portugueses na África Ocidental nos séculos XV e XVI, Lisbon, 1976; idem, Some Aspects of Portuguese Colonization and Sea Trade in West Africa in the 15th and 16th Centuries, Bloomington, IN, 1978, p. 10; Joseph Bato'ora Ballong-Wen-Mewuda, São Jorge da Mina 1482 1637. La vie d'un comptoir portugais en Afrique occidentale, 2 vols, Lisbon and Paris, 1993, vol. 2, pp. 267-69.

${ }^{2}$ John Vogt, Portuguese Rule on the Gold Coast 1469-1682, Athens, 1979, pp. 46-47, 51, 55-56; Christopher R. DeCorse, An Archaeology of Elmina. Africans and Europeans on the Gold Coast, 1400-1900, Washington, DC, and London, 2001, pp. 36-37.

${ }^{3}$ Paul Hair, The Founding of the Castelo de São Jorge da Mina. An Analysis of the Sources, Madison, WI, 1994, p. 91 n. 195, p. 92 n. 197, p. 95 n. 211.

${ }^{4}$ Philip J. Havik, 'Woman and Trade in the Guinea Bissau Region: the Role of African and Luso-African Women in Trade Networks from the Early 16th to the Mid-19th Century', Studia, (Lisbon), 52, 1994, pp. 83-120; idem, 'Comerciantes e concubinas: sócios estratégicos no comércio Atlântico na Costa da Guiné', in A dimensão atlântica da África, São Paulo, 1997, pp. 165-68. 
these works concern the second half of the sixteenth and seventeenth centuries, while here we focus on an earlier period. To these we may add a noteworthy chapter in a book by David Northrup, which ranges from the sixteenth to the nineteenth centuries. ${ }^{5}$

The aim here is to collect and examine all the available source materials in order to shed light on the role played by women in the history of Portuguese contacts with Africa in the fifteenth and early sixteenth centuries. We shall focus our attention on both African and European women involved in the cultural encounters under discussion. The way in which such encounters unfolded, as well as the results they produced, depended not only on the number of participants on each side, but also on their social status, age and sex. Hence, a women's presence, or absence, mattered at each stage of these contacts, beginning with plundering raids and ending with regular and undisturbed trade.

Europeans who embarked on expeditions to Africa constituted a specific group. They were outnumbered by Africans, with whom they fought, negotiated, or traded. These young men carried out their tasks either in a total absence of female companionship or - and this was the case only after the establishment of more regular contacts with Africa - with a very small number of women present. In Africa, the world of European sailors, merchants, conquerors, fortress builders, manufacturers and explorers was almost exclusively male. On the other hand, whole African societies encountered with European newcomers. Africans were not only more numerous, but they also differed from one another in terms of age, sex, and social function.

In the early phase of Portuguese expansion the explorers' attention was drawn to African women, seen at first mainly as slaves to be hunted for, but also as objects of sexual desire, fascination, or fear.

In 1441 a small caravel with a crew of twenty-one people commanded by Antão Gonçalves reached the Saharan coast in the region of Rio de Ouro. Several crew members went ashore in search of 'some man or woman [...] whom they could capture'. First, they came across a young man who, after being wounded, fell into the hands of his pursuers. Then they saw more people on the top of a hill and followed them, but to no avail. As the night drew closer, the Portuguese decided to retreat to their ship. As they were returning, 'they saw a black Mooress come along (who was a slave of those on the hill)'. Some suggested leaving her alone, for they were afraid it might have been an ambush. However, Antão Gonçal-

${ }^{5}$ David Northrup, Africa's Discovery of Europe 1450-1850, 2nd edn, Oxford, 2009, pp. 69-75. 
ves ordered his men to show no sign of weakness or fear and try to capture her. The people who had earlier been seen on the hill wanted to come to her rescue, but they fled once they saw that the Portuguese were ready to fight. ${ }^{6}$

Zurara again referred to the suspicion that African women might have wanted to lure the Portuguese into a trap in the account of the 1445 expedition, led by Antão Gonçalves and several other caravel commanders. ${ }^{7}$ In the area of White Cape the expedition exchanged goods with the inhabitants of the African coast. However, Gonçalves and his men remained wary and distrustful. Some hostages were exchanged on that occasion. The two Portuguese were taken to the Moors' tents, where they saw a number of beautiful women who began to seduce them, some in a very licentious way. According to the chronicler, it was the fear of running into an ambush that made the Portuguese capable of resisting their desire. 'But' - wrote Zurara - 'whether this was attempted with deceit, or whether it was only the wickedness of their nature that urged them to this, let it be the business of each one to settle as he thinks best'. ${ }^{8}$

Africans probably wanted to take advantage of the situation of the Portuguese. However, both their objectives and the outcome of their efforts remain unclear. So too does the conduct of the hostages. The sources abound in such vague fragments. The Venetian merchant Ca da Mosto, we are told, appreciated the beauty of a young slave girl whom he received from Budomel as a gift. But after sending her away to his caravel, he never spoke of her again. ${ }^{9}$ The attractiveness of an African slave girl drew the attention of Hieronim Münzer who wrote in a letter dated to around 1495 that 'Martin Behaim's father-in-law has a beautiful slave girl whom I had the opportunity to see'. ${ }^{10}$ Eustache Delafosse, in turn, described how

${ }^{6}$ Gomes Eanes de Zurara, Crónica dos feitos notáveis que se passaram na conquista de Guiné por mandado do Infante D. Henrique, ed. Torquato de Sousa Soares, 2 vols, Lisbon, 1981, vol.2, p. 86 ('por ali acudir algum homem ou mulher que eles pudessam filar'), p. 87 ('viram ir uma moura negra, que era serva daqueles que ficavam no outeiro'). Translation from The Chronicle of the Discovery and Conquest of Guinea written by Gomes Eanes de Azurara, ed. Charles R. Beazley and Edgar Prestage, 2 vols, New York, 1896, vol. 1, pp. 41, 43. In the most often quoted French translation: Gomes Eanes de Zurara, Chronique de Guinée, ed. and trans. Léon Bourdon, Dakar, 1960, pp. 80-81.

7 Zurara-Soares, Crónica, pp. 119, 179; Zurara-Bourdon, Chronique, pp. 119-125; for the dating of the expedition see n. 5 .

${ }^{8}$ Zurara-Soares, Crónica, pp. 196, 197 ('Mas se isto era enganosamente cometido, ou se a natureza maliciosa de si mesma o constrangia, fique ao encargo de cada um o determinar como lhe bem pareça'); Zurara-Beazley, The Chronicle, vol. 1, p. 111.

${ }^{9}$ Le navigazioni atlantiche del Veneziano Alvise Da Mosto, ed. Tullia Gasparrini Leporace, Rome, 1966, Il Nuovo Ramusio, vol. 5, p. 50.

${ }^{10}$ Hieronim Münzer, 'De inventione Africae maritimae et occidentalis videlicet 
some women from the settlement of Aldeia das Duas Partes enticed him into a hut and cast a spell on him. As a result, he lost two copper basins he had planned to sell. ${ }^{11}$

The intimate sphere was usually omitted from various accounts. It was quite exceptional for Zurara to include in his text the scene where African women lure the Portuguese. It testifies to the intense emotions that the incident must have aroused. All we know for sure is that the Portuguese tended to recognize the attractiveness of African women, being at the same time afraid that they might want to lure them into a trap, to cast a spell on them, or perpetrate some other ruse. In a typical medieval fashion, Zurara attributed an intrinsically wicked nature to those women.

Women also appear in historical sources as victims of slave hunting. The sources contain descriptions of both the tragedies they experienced as well as the courage some of them displayed during such 'hunts'. Zurara's chronicle describes the despair and resistance of a woman being taken into captivity. As she kept wrenching herself from her captors' grasp, making it impossible for them to take her to their caravel, they tied her up and left her in the woods, so they could freely continue their hunt for other Africans. As it turned out, the hunters did not have enough time to return for her later. Consequently, she must have been devoured by wild animals. ${ }^{12}$ Zurara also described the bravery of another woman whose resistance ended up in a profoundly moving decision. In 1445 or 1446, Alvaro Fernandes was in command of an expedition to Africa. After passing the Green Cape/Cabo Verde, the caravel reached Cabo dos Mastos. ${ }^{13}$ Sailing along the coast, the Portuguese occasionally went ashore in search of booty. One day, they saw a group of women collecting shellfish at a creek.

Geneae per Infantem Heinricum Portugalliae', in Friedrich Kunstmann, 'Hieronymus Münzer's Bericht über die Entdeckung der Guinea', Abhandlungen der Historischer Classe der Kõniglich Bayerischen Akademie der Wissenschaften, 7, 1855, pp. 290-362 (pp. 348-62), about the beautiful slave girl p. 352: '[...] socer domini Martini Bohemi habet unam pulchram schlavam, quam ego vidi.’

${ }^{11}$ Voyage d'Eustache Delafosse sur la côte de Guinée, au Portugal et en Espagne (14791481), ed. Denis Escudier, Paris, 1992, p. 30.

${ }^{12}$ Zurara-Soares, Crónica, p. 413.

${ }^{13}$ The identification of the cape is open to debate. See Zurara-Bourdon, Chronique, p. 212 n. 1; Avelino Teixeira da Mota, 'Cronologia e âmbito das viagens portuguesas de descoberla na África Ocidental, de 1445 a 1462', Boletim Cultural da Guiné Portuguesa, 2, 1947, 6, pp.315-41, on Cabo dos Mastos: p. 318; idem, Toponimos de origem portuguesa na costa ocidental de África desde o Cabo Bojador ao Cabo de Santa Catarina, Bissau, 1950, pp. 99-102, also offers a different identification of the cape, but both his proposals concern places located close to each other - south of Cabo Verde and before the Salum rivier estuary. 
They captured one of them, who would be as much as thirty years of age, with a son of hers who would be of about two, and also a young girl of fourteen years, who had well-formed limbs and also a favourable presence for a Guinea; but the strength of the woman was much to be marvelled at, for not one of the three men who came upon her but would have had a great labour in attempting to get her to the boat. And so one of our men, seeing the delay they were making, during which it might be that some of the dwellers of the land would come upon them, conceived it well to take her son from her and to carry him to the boat; and love of the child compelled the mother to follow after it, without great pressure on the part of the two who were bringing her. ${ }^{14}$

Zurara's account tends to praise the ingenuity displayed by one of the slave hunters in dealing with the captured women. Perhaps the chronicler faithfully retold the story he had heard from the participants of the expedition and, consequently, his account reflects more their view of the event than it does his. Zurara did not try to comment on the event in any direct way. Contrasted with the mother's love for her child, the Portuguese knights' cruelty and ruthlessness is felt to be particularly appalling. Notably, the scene also includes the motif of the admiration for the attractiveness of the captured girl.

Two authors described spectacular escapes attempted by some of the women whom the Portuguese had managed to capture. Attempts to break free from the hands of their persecutors were just further proof of the courage and determination African women were capable of showing. According to Zurara, in 1445, during the expedition led by Lanzarote, a Moorish girl who had been taken captive 'threw herself into the water, and like one practised in that kind of thing very quickly got to land and joined her relations and her friends'. ${ }^{15}$ Not so lucky was another slave girl who in 1480 tried to take advantage of the stopover of a few caravels on a small island near the Cape Sierra Leone. She went ashore, hid, and waited for the

${ }^{14}$ Zurara-Soares, Crónica, p. 495-96 ('e tomaram una delas que teria de idade uns 30 anos, com um seu filho que seria de dois; e assim uma moça de 14, na qual havia assaz boa postura de membros e, ainda, presence razoàvel para giuné [que era]. Mas a força da mulher era assaz para maravilhar, pois de três que se ajuntaram a ela, não havia nenhum que não tivesse bastante trabalho querendo-a levar ao batel; vendo a detença que faziam (na qual, poderia acontecer sobrechegarem alguns daqueles moradores da terra), houve um deles a resolução de lhe tomar o filho, e levá-lo ao batel; cujo amor forçou a mãe a ir-se após ele, sem muito esforço dos dois que a levavam'); Zurara-Beazley, The Chronicle, vol. 2, pp. 259-60.

${ }^{15}$ Zurara-Soares, Crónica, p. 389 ('a moura... lançou-se à água, e como acustumada em aquele trabalho, em mui breve tempo saiu em terra, entre seus parentes e amigos'); Zurara-Beazley, The Chronicle, vol. 2, p. 205. 
caravels to set sail again. She then dived into the water and started swimming in the direction of the mainland. However, it turned out that she left her hiding place too early. The caravel crews discerned the women swimming and sent a boat after her. She was thus enslaved once again. ${ }^{16}$

Such successful or unsuccessful escapes, effective or ineffective resistance, must have taken place quite often. However, the actions of these women captured the attention of eyewitnesses or chroniclers. Europeans must have considered their conduct to be at odds with the way in which women were stereotypically expected to behave. As such, these events must been highly unusual. Tales of escapes by men were omitted from accounts of European expeditions in Africa - where male Africans were concerned, the chroniclers' interest lay definitely in the recounting of their armed clashes with the Portuguese.

The examples we have seen above refer to some isolated cases, and therefore provide no sound basis for generalizations. However, what can safely be ascertained here is that in the earliest expeditionary period, Europeans noted the attractiveness of African women and appreciated their value as slaves. It was also their impressive and unusual behaviour - so far removed from European stereotypes of women's behaviour - that aroused their interest. Moreover, the Portuguese considered these women to be dangerous, as they could be used as bait in potential ambushes.

An opportunity to learn more about African women arose when the Portuguese chose to establish commercial links with Africans. Participants in the expeditions and authors of the chronicles were particularly interested in, and often truly excited about, polygamy among the Africans. ${ }^{17} \mathrm{Zu}-$ rara did not mention anything about this custom, as the witnesses he relied upon had not yet had the opportunity to learn anything about this form of African social life. What was impossible in the case of Zurara became possible for $\mathrm{Ca}$ da Mosto who observed and described polygamy among the Wolofs. The Venetian author wrote that 'The King is permitted to have as many wives as he wishes, as also are all the chiefs and men of this country, that is, as many as they can support. Thus King has always thirty of them, though he favours one more than another, according to those from whom they are descend and the rank of the lords whose daughters they are.${ }^{18}$ Ca da Mosto perspicaciously observed that polygamy did

${ }^{16}$ Voyage d'Eustache Delafosse, p. 38.

${ }^{17}$ José da Silva Horta, 'A Representação do Africano na literatura de Viagens, do Senegal à Serra Leoa (1453-1508)', Mare Liberum,1991, 2, pp. 209-338; on polygamy, see pp.321-22.

${ }^{18}$ Ca da Mosto-Leporace, Le navigazioni, pp. 42-43 ('A questo re è licito tenir quanta muier el vole; - e cossì etami a tuti li signori et homini de quel paexe: cadauno ne 
not imply all men had many wives. Possessing many wives was an option available only to those who could afford it. Thus, while there were men with numerous wives, there were also those who had no wives at all. Ca da Mosto also added:

He has certain villages and places, in some of which he keeps eight or ten of them. Each has a house of her own, with young servants to attend her, and slaves to cultivate the possessions and lands assigned by the lord [...]. When the king arrives at one of these villages, he goes to the house of one of his wives, for they are obliged to provide, out of this produce, for him and those accompanying him. [...] In this fashion he journeys from place to place without giving any thought to his victuals, and lodges sometimes with one wife, sometimes with another [...]. All the other chiefs of this country live in this same fashion. ${ }^{19}$

In Kayor, the Wolofs' state ruled by Budomel, the ruler's estates - noted Ca da Mosto - were organized along similar lines, with many wives entrusted with the task of administering them. The Venetian stayed in one of the ruler's places of residence.

In this place Budomel had nine wives: and likewise in his other dwellings, according to his will and pleasure. Each of this wives has five or six young negro girls in attendance upon her, and it is as lawful for the lord to sleep with these attendants upon her, and it is as lawful for the lord to sleep with these attendants as with his wives, to whom this does not appear any injury, for it is customary. In this way the lord changes frequently. These negroes, both men and women, are exceedingly lascivious [...].

pol tenir quante el vol, a quanta el puol far le spexe; - e cossì questo re ne ha sempre da 30 in suso, e fa però più stima de una cha de un'altra, secondo le persoe de chi le son dessesse e de la grandeza de'segnori de chi le son fiole'). For the English translation of Ca da Mosto's account I draw on the volume edited by Gerald R. Crone, The Voyages of Cadamosto and Other Documents on Western Africa in the Second Half of the $15^{\text {th }}$ century, London, 1937, p. 30.

${ }_{19} \mathrm{Ca}$ da Mosto-Leporace, Le navigazioni, pp. 43-44 ('el à certi vilazi e luogi suoi, nei qualli in algum luogo el ne tien 8 o 10, e altratante in uno altro luogo, e cossì de luogo in luogo. E chadauna de queste soe mugiere sta da per sé in chassa, e hano cadauna de esse tante femene zovene che le serve, et etiam hanno tanti schiavi per chadauna, i qualli lavorano certe possessione e tereni che'l dito signor de queste soe muier azoché de le intrade de queste terre se possano mantegnir; [...] E quando l'acade che'l dito re va ad alguno di prediti vilazi, el non porta direto né vituaria né altra cossa, perché dove el va, quelle soe muiere che là se atrovano sono obligate a farli le spexe a lui e a tuti li soi che mena con lui [...] E per questo modo el va de luogo in luogo [...] El va a dormir con una quando con l'altra de le dite soe muiere, e cresce in molto numero de fioli [...] E per questo medemo modo de sopra viveno li altri signori de quel paexe'). Translation from Ca da Mosto-Crone, The Voyages, pp.30-31. 
Writing about Wolofs' manners, Ca da Mosto noticed that local women were cheerful and very much liked dancing. ${ }^{20}$

Diogo Gomes also briefly referred to polygamy ${ }^{21}$ while further information on the topic is provided by Valentim Fernandes. In his opinion the Mandingos' customs were similar to those followed by the Wolofs. It was probably Ca da Mosto to whom they owed the information that the Mandingos' 'King and even everyone one else may have as many wives as he wishes and is able to buy', and that the ruler's wives are required to support his retinue. ${ }^{22}$ Fernandes supplemented the account of the ruler's relations with his numerous wives with the 'succession principle - each night with a different wife'. Devoted to the Mandingos was also the paragraph in which the author described the custom of buying wives. He pointed out that 'a male Mandingo can marry every woman with the exception of his mother and sister'. He also contended that one could dissolve one's marriage by returning the woman to the family from which she came, and by regaining the money with which she had been bought. ${ }^{23}$

Europeans were interested in polygamy for a variety of reasons. First of all, the practice ran counter to the Christian principle of monogamy. In Portugal, in the period under discussion, bigamy was severely punished. The culprit was sentenced to death, with the sentence being sometimes commuted to banishment to Africa. ${ }^{24}$ The most extensive and perspicacious among the accounts of West African polygamy is that offered by $\mathrm{Ca}$ da

${ }^{20}$ Ca da Mosto-Leporace, Le navigazioni, p. 53 ('In questo luogo Bodumel havea nove muiere; e altre molte muiere el tien, che sono repartide, como ho dito, in più luogi. E chadauna de queste soe muiere ha 5 over 6 garzone negre, che le serve; et è licito al signor de dormir cossi con le serve de la muier como con le muiere medesseme; né le dite soe muiere non hano per inzuria, per esser cossi la costuma: per questo el predito Bodumel muda ogni note pasto. E sono questi Negri e Negre molto luxuriosi [...]'). Translation from Ca da Mosto-Crone, The Voyages, p. 38. The information on women's cheerful disposition and dancing, Ca da Mosto-Leporace, Le navigazioni, p. 70.

${ }^{21}$ De la première découverte de la Guinée récit par Diogo Gomes (fin XVe siècle), ed. Theodore Monod, Raymond Mauny, G. Duval, texte latin et traduction française, Bissau, 1959, p. 45.

${ }^{22}$ Description de la Côte Occidentale d'Afrique (Sénégal au Cap de Monte, Archipels) par Valentim Fernandes (1506-1510), ed. Theodore Monod, Avelino Teixeira da Mota and Raymond Mauny, Bissau, 1951, p. 40 ('Elrey ou outro qualquer pode ter quãtas molheres qui ser e pode cõprar').

${ }^{23}$ Fernandes, Description, p. 48 ('Cõ todas casã tirado may e jrmãos, toda outro nõ stranham').

${ }^{24}$ Portugaliae Monumenta Africana, ed. Luis de Albuquerque and Maria E. Madeira Santos, vols 1-3, 5, Lisbon, 1993-95 (hereafter PMA), vol. 2, pp. 43-44, doc. no. 22, 12 May 1490 - the commutation of Gomes Aires' death sentence for the crime of bigamy to banishment of unlimited duration to the island of São Tomé. 
Mosto. The Venetian author revealed a political function of polygamy by indicating that women to whom rulers were married came from important families, the marriage thus being one way in which rulers forged alliances with other families. He also highlighted its economic dimension by observing that rulers' wives were entrusted with the administration of the slave villages. Ca da Mosto also attempted to look at polygamy from both the social and psychological points of view. He remarked that it was in tune with general customs and that women not only accepted the institution, but also did not protest against their husbands having sexual relationships with their servants. It was only in conclusion that he attempted to pass a moral judgment on polygamy, accepting a European point of view and stressing the promiscuity and lasciviousness of the Wolofs.

The views held by the Wolofs, as well as the way in which they perceived Europeans, must have been the mirror image of the views held by Europeans. Budomel asked Ca da Mosto about the ways of satisfying many women with which European newcomers were acquainted. ${ }^{25} \mathrm{He}$ must have assumed that the latter were particularly competent in this regard - competent and promiscuous. He probably convinced himself of European promiscuity while watching some newcomers disembark from their ships and try to make direct contact with African women.

It is Valentim Fernandes who wrote more about the relations between the Portuguese and African women. According to Fernandes,

If any of our white men stays in the house of a black man, even of the king, and asks the host for a woman or a girl, he is presented with several women out of whom he may choose those he is going to sleep with all of this happening not through coercion but out of consideration for good friendship. And it is the father of the girl chosen who takes her by the hand and gives her to the white man. The father also does not protest when the white man wants to sleep with her sisters. ${ }^{26}$

These remarks were written in the early sixteenth century. By that time, there had already developed a form of informal code of conduct (gestures, forms of behaviour) to be followed in the establishment of these types of temporary relationships between the Portuguese men and African women.

${ }^{25}$ Ca da Mosto-Leporace, Le navigazioni, pp. 53-54.

${ }^{26}$ Fernandes, Description, p. 40 ('E se alguũ dos nossos Brãcos chegua a algũa casa de Negro e esso mesmo delrey e lhe pede qualquer molher ou filha mãda lhe q escolha qualquer dellas pera dormir cõ ellas e esto por boa amizade e nõ por força $\mathrm{E}$ ho pay mesmo lha ětregua cõ a mão aquella q elle escolheo e se quer dormir com mais irmãs tãbem lhas da'). 
Thus, the phenomenon described above probably dates back to the last decades of the fifteenth century.

The condemnation of African polygamy and the criticism of their promiscuity did not prevent Europeans from taking advantage of these sexual practices. While on a long expedition, far away from their own country, and in constant contact with people from other cultures, Europeans considered themselves justified in suspending moral norms which they otherwise held. African conduct, as well as the opinions they held, were probably, as we have already suggested, the reverse of the conduct and opinions of Europeans. The accepted norms of behaviour prevalent in African society did not necessarily emerge in the contacts with Europeans.

Fernandes points out that adultery was severely punished by the Mandingos, with the punishment being meted out to the seducing man. The husband who had been cuckolded could, with the consent of the ruler, cut the culprit's skin with a knife. A long cut on the back indicated a wrongdoing. Since people used to walk naked, says Fernandes, everybody saw the long scar. ${ }^{27}$ The author does not say anything about how wives who were guilty of adultery were punished. Later sources, for example the account by Pieter de Marees, confirm that the way in which Africans treated sexual relations within their own society was different from the way in which they used to treat them with respect to Europeans. ${ }^{28}$

Fernandes's description testifies to a considerable increase in the number of sexual contacts between Europeans and Africans in comparison with the period described by $\mathrm{Ca}$ da Mosto and Diogo Gomes. Fernandes referred here to sexual relations maintained with unmarried women who were not coerced to have sex with Europeans. However, considering the fact that young girls must have felt socially constrained by parental power, the view that the sexual contacts in question were free of coercion does not seem to be justified. In any case, slaves do not feature in Fernandes's account and sexual abuse to which they may have fallen victim is not referred to in the earliest sources. It was not until the end of the fifteenth century that some authors began to allude to such situations. We shall return to this problem later.

The names of Africans - those of rulers, tribal chiefs, and their relatives - already appear in the sources recounting the earliest phase of

${ }^{27}$ Ibid.

${ }^{28}$ Pieter de Marees, Beschryvinge ende historische verhael van het Gout koninckrijk van Gunea, anders de Gout-custe de Mina genaemt, Amsterdam, 1602, preface and chapter 2 on marriages and chapter 7 on female behavior. English edition: Pieter de Marees, Description and Historical Account of the Kingdom of Guinea (1602), ed. Albert van Dantzig, and Adam Jones, Oxford, 1987, pp. 11, 20-21, 37. 
the Portuguese exploration of Africa. Occasionally chronicles mention the names of important warriors or even captives and slaves who distinguished themselves in some way. But there are no names of women a small number of freed slaves are the only exceptions. Women who for some time maintained intimate relationships with Europeans remained nameless until the end of the fifteenth century. Their names began to appear at the beginning of the sixteenth century, after fifty years of contact between the Portuguese and Africans. This should be regarded as proof that they were treated instrumentally.

As we have already seen, Portuguese women did not take part in the first expeditions to Africa. However, it does not mean that the expeditions did not affect their lives. The wives of the knights who were killed in Africa were granted privileges that allowed them to maintain their social status. They were offered either land grants or special pensions (teença) paid by the royal treasury. ${ }^{29}$ Even if a man were not killed in Africa, long separations often ended in a break-up of the family. In 1488 Ines Eanes was tried for eloping with a João Dias, having first got married to Alfonso Dias who died in Mina. Her marriage to Alfonso Dias was also illegal, as it turned out to be bigamous. Her lawful husband, Gonçalo Eanes, was still alive, although she had not seen him for a long time. Acting on behalf of the king, judges came to the conclusion that Ines's long separation from her husband, along with the life of uncertainty she had to live, should be counted as extenuating circumstances and decided to grant her a pardon. ${ }^{30} \mathrm{Her}$ case was not an isolated example. In 1490, Ines Pires, João Marinho's wife, was also tried for bigamy and was similarly pardoned. She remarried as her lawful husband stayed overseas as he had been exiled for five years. Her pardon was justified on the grounds that there were rumors of her husband's death at Mina fortress. He was to have been killed, along with other men gathered around a João Fagaça, in an unknown battle. Since the rumor was false, Ines Pires's marriage turned out to be bigamous. ${ }^{31}$ In 1501 Margarida Fernandes, Alvaro Gil's widow - Gil had gone to Elmina - was granted a pardon. She was tried and convicted for adultery, but was then pardoned when it was revealed that her husband had died at Mina. ${ }^{32}$ Long

${ }^{29}$ PMA, vol. 1, p. 39, doc. no. 10, 12 December 1453 - the granting of the pension (teença) to Pedro Anes Encerrabodes's widow. For more on such privileges see: Michał Tymowski, 'Death and Attitudes to Death at the Time of Early European Expeditions to Africa (15th Century)', Cahiers d'Études africaines, 54, 2014, 215 (3), pp. 787-811, on privileges: p. 802.

${ }^{30}$ PMA, vol. 1, pp. 408-09, doc. no. 207, 4 March 1488.

${ }^{31}$ PMA, vol. 2, pp. 48-49, doc. no. 25, 5 June 1490.

32 PMA, vol. 3, p. 183, doc. no. 109, 11 October 1501. 
separation from spouses who had gone to Africa - either of their own accord or as exiles - painfully affected the life of the wives.

The earliest information about women who travelled to Africa is connected with São Jorge da Mina castle. Six hundred men, including five hundred soldiers and one hundred craftsmen, took part in the expedition led by Diogo de Azambuja who in 1482 supervised the construction of the castle. A few women were assigned to the expedition, although their exact number remains unknown. In any case, after the castle had been built, Azambuja sent most members of the expedition back to Portugal, while he remained in Africa with sixty soldiers and three women. He spent two years and seven months in Mina organizing a trading post. These events are described in several sources, ${ }^{33}$ but it was only Rui de Pina who offered some information about these women. ${ }^{34}$

The 12 July 1499 report, prepared by captain Lopo Soares and other officials who were about to leave their post at Mina, mentions seven women who stayed at the castle. ${ }^{35}$ The women were not black slaves but the Portuguese sent to Mina as exiles (degradadas). According to Hair, such a punishment was usually meted out to prostitutes, not because they were prostitutes but because of the crimes they committed while plying their trade, such as theft. ${ }^{36}$ Two documents, dated 1 February 1509 and 1 March 1509 , contain the list of the castle's residents. The preparation of such a list was occasioned by the distribution of bread rations. The first document mentions as a separate category four women, giving both their first and second name. Catarina, Fernan d'Avila's wife, was put on the list separately. She and her husband are referred to as the king's slaves (escravos del-Rei noso senhor). It is likely that they were also degradados sent into ex-

${ }^{33}$ Rui de Pina, Crónica de el-Rei D. João II, ed. Alberto Martins de Carvalho, Caimbra, 1950. Paragraphs concerning the construction of Mina in: Monumenta Missionaria Africana, vol. 1: Africa Ocidental (1471-1531), ed. Antonio Brásio, Lisbon, 1952 (hereafter MMA), pp. 8-14, on women p. 14; João de Barros, Ásia. Dos feitos que os Portugueses fizeram no descobrimento e conquista dos mares e terras do Oriente. Primeira década, sexta edição actualizada e anotada por Hernani Cidade, notas por Manuel Múrias, Lisbon, 1945, Liv. 3, cap. 1-2, pp. 77-85; Duarte Pacheco Pereira, Esmeraldo de situ orbis, ed. Raymond Mauny, Bissau, 1956, pp. 120-23. All the sources are analysed and quoted - both in original and in English translation - by Hair, The Founding. See also, Michał Tymowski, 'Europeans and Africans in the Early Period of Portuguese Expansion in Africa - the Organization and Course of the First Encounters', Hemispheres, 25, 2010, pp. 95-122. For sources on the founding of the castle: pp.99-100,107-15.

${ }^{34}$ Pina, in MMA, p. 14; Hair, The Founding, pp. 36, 102; see also Pina in John W. Blake, Europeans in West Africa, 1450-1560, Nendeln, 1967, p. 77.

${ }^{35}$ Descobrimentos portugueses, ed. João Martins da Silva Marques, 3 vols, Lisbon, 1944-71, vol. 3, p. 525, 12 July 1499.

${ }^{36}$ Hair, The Founding, p. 92. 
ile together as a married couple. Mina's captain, Afonso de Babadilha, appears in the list along with his wife and twenty-eight other persons who usually surrounded him. Other high ranking officials - factor (an official put in charge of a trading post), judge, and scribes - are mentioned without their wives. In total, the 1 February 1509 list contains seventy-eight men and six women. ${ }^{37}$

The list drawn up a month later includes 131 men and seven women. The group of six women mentioned above was joined by one further person. She came from Axim, along with a large group of men who considerably raised the total number of the castle's population. ${ }^{38}$ With people on the move, the number of those who made up the garrison altered, but women were constantly outnumbered by men. While Diogo de Azambuja remained in command, there was one Portuguese woman for every twenty men, one woman for every thirteen men in February 1509, and one woman for every nineteen men on 1 March 1509.

In 1529 Emanuel I the Fortunate issued a decree (regimento) concerning the administration of São Jorge da Mina. ${ }^{39}$ This regimento was based on a previous decree issued in 1506. Both documents are likely to have drawn on principles elaborated by Diogo de Azambuja. Both the 1506 decree and Azambuja's principles are now lost. ${ }^{40}$ The 1529 document defines the rules and principles on which the life and work of European women staying in Mina were to be based. The women were referred to as molheres solteiras: that is, single and unmarried. The thirty-fifth paragraph explains their duties. They were supposed to work at the hospital and take care of the sick. They were also required to work in the bread ovens, mill flour, wash clothes, and perform a variety of other tasks. Just like the remaining members of the castle garrison, they were entitled to a daily ration of bread, oil and vinegar, as the documents from 1509 also inform us. They had slave women at their disposal. The high ranking officials were forbidden from monopolizing the services of the molheres solteiras under pain of losing their pay. In short, they could not use these women exclusively. The women, in turn, were forbidden - also under the threat of losing their pay - from working only for the officials, while

${ }^{37}$ PMA, vol. 5, pp. 490-94, doc. no. 130,1 February 1509.

38 PMA, vol. 5, pp. 504-09, doc. no. 138, 1 March 1509.

39 The text of Regimento in Ballong-Wen-Mewuda, São Jorge da Mina, vol. 2, pp. 542-69. See also: Jorge Faro, 'Estêvão da Gama capitão de S. Jorge da Mina e a sua organização administrativa em 1529', Boletim Cultural da Guiné Portuguesa, 12, 1957, 47, pp.385-442.

${ }^{40}$ David Birmingham, 'The Regimento de Mina', Transactions of the Historical Society of Ghana, 9, 1970, pp. 1-7; DeCorse, An Archaeology, pp. 36-37; Vogt, Portuguese Rule, p. 182. 
they were also to be properly paid for working for the entire garrison. ${ }^{41}$ There is no doubt that these regulations were issued as a response to the appropriation of the women's work or even their persons by high ranking officials. One can also hold serious doubts about how enforceable these rules were.

The paragraph discussing female working practices has provoked a scholarly discussion. Teixeira da Mota and later Hair claimed - their interpretation of the respective fragment being consistent with other sections of the regimento - that these 'other tasks' for which the women were to be paid were sexual in nature..$^{42}$ According to Ballong-Wen-Mewuda, this paragraph needs to be interpreted in a different way. In his opinion, the king stood guard over the women's chastity. ${ }^{43}$ I find the interpretation put forward by Teixeira da Mota and Hair more convincing. It is more plausible, particularly in the context of the whole regimento. There can also be no doubt that a small number of women provoked tension and conflicts among the male garrison of the castle, both over ordinary household chores like washing and over their intimate life as well.

The regimento also reveals that the molheres solteiras were assigned African slave women on whose help they could rely. Undoubtedly, a general lack of female companionship led the castle's inhabitants to become increasingly interested in African women, both as slaves and free women. There are a few documents testifying that there were African slave women who, after living for some time in Portugal, were sent back to Africa in the king's service. The first dates from 1454. It says that Alfonso V would free a slave, Fatima, provided she went to Africa as his servant. ${ }^{44}$ The second document is dated 20 April 1499 and states that Emanuel the Fortunate liberated one of his slaves, Beatriz Gomes. ${ }^{45}$ Beatriz had probably been sent from Portugal to Mina where, after serving there for some time, she was liberated and granted the right to return and live in the kingdom. These were exceptional situations. There was no point in sending slave women from Portugal to Africa in order to burden them with household tasks. Those African slave women who were sent from Europe to Africa probably served as interpreters, while those entrusted with mundane jobs were placed in the castle right after being captured or purchased in Africa.

\footnotetext{
${ }^{41}$ Regimento, capitulos 35, 36, 37.

${ }^{42}$ Mota, Some Aspects, pp. 10-11; Hair, The Founding, p. 92.

${ }_{43}$ Ballong-Wen-Mewuda, São Jorge da Mina, p. 267.

${ }^{44}$ PMA, vol. 1, doc. no. 11, 17 May 1454, p. 40; it was also published in Monumenta Henricina, ed. Antônio Joaquim Dias, 15 vols, Coimbra, 1960-1974, vol.11, p. 351.

${ }^{45}$ PMA, vol. 2, doc. no. 239, p. 407.
} 
The 1519 document enumerates African slave women working at the castle, as it does their duties and some of their owners. ${ }^{46}$ Magdalena, Isabel, Margarida with her son, and Antonia with her two sons worked at the bread ovens. Catarina, Margerida and Cristova served in the captain's house. Catarina, Francisca, and Catarina's daughter served in the house of the factor. Ines, with her daughter, worked in Pedro de Seixas's house. Mecia and her daughter were in the service of the people referred to as residents. Brizida and her two daughters remained in the service of a judge (alcaide-mor). Maria Velha was also in the service of residents, as were two other Marias. Garcia worked with her four sons at the bread ovens, while Francisca and her daughter served in Francisco de Seixas's house, and Guimara with her son worked for residents.

Thus, we have evidence that eighteen African slaves served in the houses of high ranking officials and ordinary members of the garrison (that is probably how the term 'residents' needs to be understood). We know about some of their duties, especially at ovens. The remaining slave women worked as domestic servants. Nine slave women had children, some of them two, and one of them as many as four. This is proof that their owners, and perhaps other people as well, abused them sexually. Children, or at least some of them, were not taken away from their mothers and sold. The children were also slaves. One of the daughters, clearly older than the remaining children, worked - just like her mother - as a servant. If the children were the offspring of a slave owner, they could be liberated, their liberation probably taking place at an older age when they were no longer in their mother's care. At any rate, the document clearly proves that some slave women were placed in the houses of their owners for whom they worked and for whom they provided a variety of services, including, perhaps, sexual ones. The presence of these women made the gender ratio at least a little less unfavourable to men. As a consequence, there also appeared at Mina, and indeed at other places where the Portuguese stayed a group of mulattos, although they are not mentioned in the 1519 document. Their existence is attested to in later sources, and I shall return to this problem.

In São Jorge da Mina it was also possible for Europeans to maintain relationships with free African women. The early evidence is to be found in the account of Eustache Delafosse's journey to the coast of Mina in 1481 - the castle São Jorge da Mina had not yet been built - to the settlement called

${ }^{46}$ The quotation from the 1519 document follows Ballong-Wen-Mewuda, São Jorge da Mina, vol. 1, pp. 267-68. The document comes from the Archive of Torre do Tombo, corpo cronologico II-85-75, fol. 13. 
Aldeia das Dues Partes. We have already mentioned how the merchant of Bruges was seduced by local women. ${ }^{47}$ However, a small dictionary which Delafosse included in his account offers a more telling testimony in this regard. Among few words existing in the Akan and Mande languages there is a word chocque-chocque which means making love. ${ }^{48}$ According to studies carried out by Hair and David Dalby the word is not derived from any of the African languages. Instead, it is a Portuguese slang term for sexual intercourse which was also used in Angola and Morocco ${ }^{49}$ A merchant of Bruges, probably a Fleming, Delafosse did not understand Portuguese and took chocque-chocque for an African word, not least because it was also used by the women who were trying to seduce him.

The Portuguese reached the coast of Mina in 1471. As Delafosse's account shows, it took only ten years for this word to become embedded in the local language. This is evidence that the newcomers (who arrived in Mina Coast for only a short stay) were quick to establish intimate relations with local women. In 1482, in the village visited by Delafosse, the Portuguese built a castle which was to be constantly occupied by several dozen men. From that moment on the contacts in question only intensified. An African village grew under the walls of the castle. The castle soldiers visited the village in search of sexual partners, both regular and casual. If a couple established a permanent relationship, it was considered a marriage. In the late sixteenth and early seventeenth centuries there were many mulattos born to such couples. They served as intermediaries in contacts between Africans and Europeans. ${ }^{50}$

There is evidence that points to the existence of sexual relationships between African women and European men, and even European women and African men - the latter being rare due to the small number of European women travelling to Africa - from the very beginning of the settlement of the island of São Tomé. According to Valentim Fernandes, when both spouses were white, the women did not get pregnant. It was mixed marriages that had children - regardless of whether it was a wife who was black or a husband (muito mais poré as aluas das negros e as negras dos

${ }^{47}$ Voyage d'Eustache Delafosse, pp. 28, 30.

${ }^{48}$ Ibid.

${ }^{49}$ David Dalby and Paul Hair, 'A Further Note on the Mina Vocabulary of 14791480', Journal of West African Languages, 2, 1968, p. 131 n. 14.

50 de Marees-Dantzig-Jones, Description, p. 26 n. 3; Vogt, Portuguese Rule, pp. 179, 182; DeCorse, An Archaeology, p. 37; Harvey Feinberg, Africans and Europeans in West Africa: Elminas and Dutchmen on the Gold Coast during the Eighteenth Century, Philadelphia, PA, 1989, pp. 36, 88-92. 
homés aluos). ${ }^{51}$ This remark referred to the group of two thousand Jewish children, none of which were older than eight years of age, sent to the island in 1492. Six hundred managed to survive the harsh climate and came of age. One might guess that the situation was similar for other mixed couples, with the difference being that among the Portuguese who, either of their own accord or as exiles, travelled to the island, men overwhelmingly outnumbered women. The gender ratio among the Jewish children must have been more balanced.

Fernandes notes that one thousand Portuguese inhabited the island at the beginning of the sixteenth century. Only some of them were there of their own accord. Some came to the island from Guinea for commercial purposes, and they stayed there for only a short time. Exiles made up the largest group of the island's inhabitants (pore os mais som os degredados).$^{52}$ The king ordered that all who arrived on the island as a degradado were to receive a slave who would help them. It was for each degradado to decide whether they wanted to rely on the assistance of a male or female slave. Some degradados became wealthy enough to have fourteen or more slaves. The slaves grew yams and millet for their masters. Fernandes estimated that there must have been about two thousand slaves living on the island permanently. Moreover, there were about five or six thousand slaves staying on the island for a brief period of time while waiting to be sold elsewhere..$^{53}$ The information given by Fernandes is confirmed in the document from 4 November 1508. The document is an inventory of property owned by Alvaro Borges who died on the island of São Tomé. Added to the inventory is the list of the items that were sold on 8,15 , and 25 November of that year. ${ }^{54}$

The inventory clearly shows that Borges had ten female slaves and eight male slaves. All female slaves that belonged to the deceased and remained on the island for a longer period of time had one or two children. The only childless slaves were those who had been brought to the island relatively recently. The first slave woman to be mentioned in the inventory was one 'by the name of Jabell, along with her one year old son, a mulatto - the son of Lop Eanes to whom she - as a slave of the

${ }^{51}$ Fernandes, Description, p. 118; see also Pina-Carvalho, Crónica, cap. 150; Raymond Mauny, 'Le Judaïsme, les Juifs et l'Afrique Occidentale', Bulletin IFAN, 3-4, 1949, pp. 354-78.

${ }^{52}$ Fernandes, Description, p. 120.

${ }^{53}$ Ibid.

${ }^{54}$ PMA, vol. 5, p. 221-43, doc. no. 89, 4 November 1508 ('Item primarremente hũa escrava por nome Jabell com filho mulatto de hum anno filho de Lop'Eanes a quall escrava sse achou que era del-Rei nosso senhor que lhe tynham dado de ordenado'). 
king, our lord - had been made over according to the king's decrees'. We do not know how Alvaro Borges became the owner of the slave women and her son. The document did not include Jabell and her son among the group of slaves who were sold. Perhaps, which is unlikely, they were sold nameless, or, quite the contrary, they were freed. One way or another, the document attests to a relationship between a white man and a black woman. The relationship, as well as the resulting son, were not a secret, nor were they frowned upon. Moreover, it was not her owner, but another man who fathered her son. He was her previous owner. A young mulatto by the name of Bras was among those who attempted to purchase the property left by Alvaro Borges, and it was mainly slaves that were bought. ${ }^{55}$ This illustrates that it was possible for children born to mixed couples to be freed and pursue lucrative business ventures.

These isolated cases known from the 1508 document are attested to as quite typical in the description of the journey from Lisbon to the São Tomé by an anonymous Portuguese pilot. The text was written around 1535 , but it is only the sixteenth century Italian translation that survives, which was printed in 1550 in the Ramusio collection. ${ }^{56}$ According to the pilot, São Tomé was permanently inhabited by $600-700$ families, including merchants of various descent. So there were, among others, Portuguese, Castilian, Genoese, and French merchants. Whoever wanted to live on the island was welcomed.

They all have wives and children, and some of the children who are born there are as white as ours. It sometimes happens that when the wife of merchant dies he takes a negress and this is an accepted practice, as the negro population is both intelligent and rich; the children of such unions are brought up to our customs and way of dressing. Children born of these negresses have lighter skin, [are mischievous and difficult to manage] and are called Mulati (mulatoes). ${ }^{57}$

${ }^{55}$ Ibid., p. 240.

56 'Navigazione da Lisbona all'isola di San Tomé, in Giovanni Battista Ramusio, Navigazioni e viaggi, ed. Marica Milanesi, vol. 1, Turin, 1978, pp.565-88; see also Rinaldo Caddeo, Le navigazioni atlantiche di Alvise da Ca' da Mosto, Antoniotto Usodimare e Niccoloso da Recco, Milano, 1928, pp. 297-328. For an English translation see Blake, Europeans in West Africa, pp. 145-66 and for the French see Serge Sauvageot, 'Navigation de Lisbonne à l'Ile São Tomé par un pilote portugais anonyme (vers 1545)', Garcia de Orta, 9 , 1961, pp. 123-38.

57 'Navigazione', p. 578: ‘[...] e tutti hanno moglie e figliuoli. E sono quelli che nascono in detta isola bianchi come noi, ma alle volte accade che detti marcatanti, morendoli le mogli bianche, ne prendono delle negre: nel che non vi fanno troppo difficulta, essendovi abiatori negri di grande intellecto e ricchi, che allevano le loro figliuole al modo nostro nell costumi e nel vestire. E quelli che nasco di queste tal 
Marriages between African women and the so-called lançados - the Portuguese who fled to Africa where they were beyond the reach of royal power - present a separate category. ${ }^{58}$ One of the motives that stood behind such escapes - apart from the intention to get away with a crime, to win freedom, to profit from conducting some trade, or to embark on an exciting adventure - was the search for women. Lançados preserved their ability to speak Portuguese, while the women they were with enabled them to develop close ties to African clans. ${ }^{59}$ Their wives played an important role in organizing trade relations between the Portuguese and Africans. They served as interpreters and provided their husbands with information on local customs. ${ }^{60}$ Gradually lançados adopted many elements of the African culture in which they operated, including local beliefs. Children born out of such relationships acquired a knowledge of both cultures that of the father and the mother. Consequently, there appeared a distinct ethnic group of Luso-Africans speaking crioulo, that is, a simplified Portuguese. $^{61}$

Figures of African women were one of the common topics of the sculptures created by the people Sapi (Temne) from Sierra Leone which is where many lançados settled. They served as agents for trade with the Portuguese, with ivory sculptures serving as an important product. These were salt cellars, spoons and knife handles. Sometimes whole tusks were covered with carvings. Images of African women appeared particularly on salt cellars. The sculptures presented women performing different roles. Sometimes they were shown accompanying men and they were occassionally depicted alone, while some of the images are profoundly erotic. ${ }^{62}$

negre sono berrettini, e vengono chiamati mulati.' The remarks concerning difficulties in raising children are absent from the Ramusio edition prepared by M. Milanesi and based on the first 1550 edition. Blake, Europeans in West Africa, p. 157, includes the remarks in his translation: 'Children born of these negresses are mischievous and difficult to manage, and are called Mulati [mulatoes].' The information about the lighter colour of these children's skin is omitted from Blake's translation. This highlights the discrepancies between the first and the second edition of 1554 (p.145).

${ }^{58}$ Walter Rodney, A History of the Upper Guinea Coast 1545-1800, Oxford, 1970, pp. 74-94; Maria da Graça Garcia Nolasco da Silva, 'Subsidios para o estudo dos "lançados” na Guiné’, Boletim Cultural da Guiné Portuguesa, 25, 1970, no. 97, pp. 25-40, no. 98, pp. 217-32, no.99, pp.397-420, no. 100, pp. 513-60; Jean Boulègue, Les Luso-africains de Sénégambie, XVI $-X I X^{e}$ siècles, Lisbon, 1989; George Brooks, Landlords and Strangers: Ecology, Society and Trade in Western Africa, 1000-1630, Boulder, CO, 1993, passim.

${ }^{59}$ Mota, Some Aspects, p. 8; Peter Mark, Portuguese Style and Luso-African Identity: Precolonial Senegambia, Sixteenth-Nineteenth Centuries, Bloomington, IN, 2002.

${ }^{60}$ See works by Havik quoted in footnote 4.

${ }^{61}$ Boulègue, Les Luso-africains; Mark, Portuguese Style.

${ }^{62}$ William B. Fagg, Afro-Portuguese Ivories, London, 1959, p. X ('representation of a woman blatantly displaying her sexual organs'), also il. 1, 4, 5; Ezio Bassani and 
These iconographic sources are in line with written accounts, and therefore enhance the credibility of the latter.

Thus, in the early period of the cultural encounter between Europeans and Africans, women from both sides performed numerous roles. African women can be regarded as playing the role of victims of slave hunting, but also of symbols of brave resistance. They also played the role of real, or alleged, seductresses who attempted to lure white assailants into traps. After the contacts stabilized, the female role became that of occasional mistresses or of regular partners of castle inhabitants at São Jorge da Mina. They were also the wives of lançados, which enabled them to establish contacts within African societies. Finally they were mothers of mulattos, a distinct group that also made contacts across the ethnic divide easier.

Portuguese women did not participate in the earliest expeditions to Africa, although the expeditions affected their lives. They were the victims of long periods separated from their husbands. Some of those women passively resigned themselves to their fate, while others tried to find a way out of their difficult situation. However, few European women travelled to Africa. Those who did assumed a double role. At first, these women were degradadas, sent into exile either to the São Jorge da Mina castle or to the island of São Tomé where they were supposed to serve the Portuguese garrison, which included sexual acts. Black slave women freed in Portugal were sent back to Africa as interpreters. Still less numerous were the wives of Portuguese officials travelling with their husbands to Mina or to São Tomé. The number of free Portuguese women staying in Africa was also very small.

Initially, the vast majority of women representing both sides of the contacts in question acted under coercion. This is most obviously seen with regard to black slave women captured in Africa and Portuguese women sent there into exile. Once contacts were established on a more regular basis, resulting in the development of trade between the Portuguese and Africans, the number of black slave women increased. At the same time, there appeared a large number of African women who came into contact with Europeans of their own accord. A small group of those women inhabited the area around São Jorge da Mina fortress and around Axim. The most numerous were the wives of the lançados,

William B. Fagg, Africa and the Rennaissance: Art in Ivory, New York, 1988, catalogue no. 8 , and il. 43, p. 66 and detail il. 156, p. 124 and catalogue no. 16 and il. 186, p. $145-$ both illustrations show carved saltcellars of Sapi. The first represents women performing sexual gestures. The second shows women accompanying men. 
whose position was particularly strong, since they lived in their own environment while the Portuguese fugitives were new to it.

A great number of women were treated instrumentally, which is clearly attested to by the fact that their names were never mentioned. Women banished to Africa or freed on the condition they went to the Africa were the exception. Both banishment and liberation required taking legal action which, in turn, resulted in the production of documentation by respective offices. Also known were the names of wives of the Portuguese high ranking officials and sometimes the names of distinguished wives of lançados. As is often the case with respect to other epochs and other continents, in Africa of the fifteenth and early sixteenth centuries the sources give the names of people from the top and bottom of the social hierarchy. The names of ordinary people, those in the middle, including the vast majority of both European and African women, remain unknown.

The descriptions of women to be found in the sources relating to the period under discussion - whether individual persons or those representing social groups - are one-sided. This one-sidedness is overwhelming and much greater than that typifying the descriptions of both Europeans and African. Moreover, we have only European sources at our disposal, each written exclusively by a man. No woman left either a written account or an artistic representation of the events dealt with here. Not only do women participating in the Portuguese-African contacts remain anonymous, but no source survives which records their own point of view. There is also no evidence of the activities the women were involved in for long periods of time. A group of lançados's wives is an exception. This group is known to have been active for a few centuries. Usually, we have to content ourselves with the knowledge of a brief episode in the lives of particular women which a given source happened to record. Besides, it is always a male opinion. These historical accounts present male points of view because men were always the authors.

As a result, there remain many questions to which we cannot find answers. Despite these limitations, we are able to say that women played an important role in cultural encounters between Europeans and Africans and to a great extent affected the conduct of men taking part in these contacts. 


\section{Summary}

The author's aim is to describe and analyse the role of women in the early Portuguese expeditions to West Africa. Women did not participate in the first expeditions. For the first few decades the expeditions were the domain of young, risk-taking men. A small number of women appeared in Africa in the last quarter of the fifteenth century as the so-called degradadas began to be sent to São Jorge da Mina castle and St Tomé island. The author analyses chronicle accounts and legal regulations referring to women sent into exile in the Dark Continent. African women, in the period of armed raids and plunder,were carried away into captivity. Thus, in the early phase of the Portuguese expeditions, most women acted under coercion. This concerns both slave women as well as degradadas. Few women are mentioned by their names in historical sources. Most remain nameless, which proves that they were treated instrumentally. In the second half of the fifteenth century, as the relations with Africans stabilized and trade began to grow, women were given new social and economic roles to play in European-African contacts. Both free and slave African women entered into relationships with European newcomers. African wives, the so-called lançados, became quite independent.

(Translated by Artur Mękarski) 